\title{
Correction to: Melatonin and urological cancers: a new therapeutic approach
}

\author{
Mohammad Hossein Pourhanifeh ${ }^{1}$, Azam Hosseinzadeh², Kobra Bahrampour Juybari ${ }^{3}$ and Saeed Mehrzadi ${ }^{2 *}$ (0)
}

\section{Correction to: Cancer Cell Int 20:444 (2020) https://doi.org/10.1186/s12935-020-01531 $-1$}

Following publication of the original article [1], we were notified of a mistake in the spelling of the first author.

- Incorrect spelling: Mohammad Hossein Mehrzadi

- Correct spelling: Mohammad Hossein Pourhanifeh

\section{Reference}

1. Pourhanifeh MH, Hosseinzadeh A, Juybari KB, Mehrzadi S. Melatonin and urological cancers: a new therapeutic approach. Cancer Cell Int. 2020;20:444. https://doi.org/10.1186/s12935-020-01531-1.

\section{Publisher's Note}

Springer Nature remains neutral with regard to jurisdictional claims in published maps and institutional affiliations.

The original article has been corrected.

\section{Author details}

${ }^{1}$ Research Center for Biochemistry and Nutrition in Metabolic Diseases, Kashan University of Medical Sciences, Kashan, Iran. ${ }^{2}$ Razi Drug Research, Center, Iran University of Medical Sciences, Tehran, Iran. ${ }^{3}$ Department of Pharmacology, School of Medicine, Semnan University of Medical Sciences, Semnan, Iran.

Published online: 28 September 2020 in this article are included in the article's Creative Commons licence, unless indicated otherwise in a credit line to the material. If material is not included in the article's Creative Commons licence and your intended use is not permitted by statutory regulation or exceeds the permitted use, you will need to obtain permission directly from the copyright holder. To view a copy of this licence, visit http://creativecommons.org/licenses/by/4.0/. The Creative Commons Public Domain Dedication waiver (http://creativecommons.org/publicdomain/zero/1.0/) applies to the data made available in this article, unless otherwise stated in a credit line to the data. 